\title{
Analysis of radiofrequency lesions in egg whites in vitro produced by application of the Tew electrode for different temperatures and times
}

\author{
Young Suk Kwon MD¹, So Young Lim MD PhD¹, Jong Ho Kim MD¹, Ji Su Jang MD¹, Chul Ho Kim MD², \\ Kwang Jun Kwon $\mathrm{MD}^{3}$, Jun Heum Yon MD PhD
}

YS Kwon, SY Lim, JH Kim, et al. Analysis of radiofrequency lesions in egg whites in vitro produced by application of the Tew electrode for different temperatures and times. Pain Res Manag $2015 ; 20(6): 316-320$.

BACKGROUND: Understanding the size and shape of radiofrequency lesions is important to reduce side effects when applied to patients. OBJECTIVES: To investigate the radiofrequency lesions produced by the application of the Tew electrode for different temperatures and times. METHODS: The white from a fresh hen's egg was placed in a rectangular glass container and warmed to $37^{\circ} \mathrm{C}$. After immersion of the Tew electrode in the egg white, radiofrequency lesions were produced at $65^{\circ} \mathrm{C}, 70^{\circ} \mathrm{C}$, $75^{\circ} \mathrm{C}, 80^{\circ} \mathrm{C}, 85^{\circ} \mathrm{C}$ and $90^{\circ} \mathrm{C}$. For each temperature, photographs were taken at $10 \mathrm{~s}, 20 \mathrm{~s}, 30 \mathrm{~s}, 40 \mathrm{~s}, 50 \mathrm{~s}, 60 \mathrm{~s}, 70 \mathrm{~s}, 80 \mathrm{~s}, 90 \mathrm{~s}, 100 \mathrm{~s}, 110 \mathrm{~s}$ and $120 \mathrm{~s}$. The size of the lesion was measured at each temperature and time. A mixed model was used to analyze the data.

RESULTS: The size of the lesion increased with increasing temperature and time. There were statistically significant differences in the size of the internal radius between the $65^{\circ} \mathrm{C}$ and $70^{\circ} \mathrm{C}$ groups and the $70^{\circ} \mathrm{C}$ and $75^{\circ} \mathrm{C}$ groups, as well as in the $70^{\circ} \mathrm{C}$ and $75^{\circ} \mathrm{C}$ groups in the size of the external radius and the $60^{\circ} \mathrm{C}$ to $80^{\circ} \mathrm{C}$ groups in the size of the distal radius. The maximum lesion size was produced at $90^{\circ} \mathrm{C}$ and $120 \mathrm{~s}$, and was $1.06 \pm 0.16 \mathrm{~mm}$ in internal radius, $0.37 \pm 0.15 \mathrm{~mm}$ in external radius, $0.39 \pm 0.04 \mathrm{~mm}$ in distal radius.

CONCLUSION: The Tew electrode produces lesions following the contour of the tip, and the internal radius is larger than the external and distal radius. The best combination of temperature and time for lesioning using the Tew electrode is $80^{\circ} \mathrm{C}$, for $60 \mathrm{~s}$ to $90 \mathrm{~s}$.

Key Words : Egg white; Electrode; Lesion size; Radiofrequency

\author{
L'analyse des lésions de radiofréquence dans des \\ blancs d'œuf in vitro, produites par l'application de \\ l'électrode Tew à différentes températures et \\ pendant des durées plus ou moins longues
}

HISTORIQUE : Il est important de comprendre la dimension et la forme des lésions de radiofréquence pour en limiter les effets secondaires chez les patients.

OBJECTIFS : Examiner les lésions de radiofréquence produites par l'application de l'électrode Tew à différentes températures et pendant des durées plus ou moins longues.

MÉTHODOLOGIE : Les chercheurs ont placé le blanc d'un œuf de poule frais dans un contenant rectangulaire en verre et l'ont chauffé à $37^{\circ} \mathrm{C}$. Après y avoir immergé l'électrode Tew, ils ont produit des lésions de radiofréquence à $65^{\circ} \mathrm{C}, 70^{\circ} \mathrm{C}, 75^{\circ} \mathrm{C}, 80^{\circ} \mathrm{C}, 85^{\circ} \mathrm{C}$ et $90^{\circ} \mathrm{C}$. À chaque température, ils ont pris des photos au bout de $10 \mathrm{~s}, 20 \mathrm{~s}, 30 \mathrm{~s}, 40 \mathrm{~s}, 50 \mathrm{~s}, 60 \mathrm{~s}, 70 \mathrm{~s}$, $80 \mathrm{~s}, 90 \mathrm{~s}, 100 \mathrm{~s}, 110 \mathrm{~s}$ et $120 \mathrm{~s}$. Ils ont mesuré la dimension de la lésion à chaque température et au bout de chaque durée. Ils ont utilisé un modèle mixte pour analyser les données.

RÉSULTATS : La dimension de la lésion augmentait proportionnellement à la température et à la durée. Il y avait des différences statistiquement significatives dans la dimension du rayon interne entre les groupes de $65^{\circ} \mathrm{C}$ et de $70^{\circ} \mathrm{C}$ et entre ceux de $70^{\circ} \mathrm{C}$ et $75^{\circ} \mathrm{C}$, de même que dans la dimension du rayon externe dans les groupes de $70^{\circ} \mathrm{C}$ et $75^{\circ} \mathrm{C}$ et dans la dimension du rayon distal dans les groupes de $60^{\circ} \mathrm{C}$ à $80^{\circ} \mathrm{C}$. Les lésions atteignaient leur dimension maximale à $90^{\circ} \mathrm{C}$, au bout de $120 \mathrm{~s}$, d'un rayon interne de $1,06 \pm 0,16 \mathrm{~mm}$, d'un rayon externe de 0,37 $\pm 0,15 \mathrm{~mm}$ et d'un rayon distal de $0,39 \pm 0,04 \mathrm{~mm}$.

CONCLUSION : Les électrodes Tew produisent des lésions qui suivent le contour de leur pointe, et le rayon intérieur est plus grand que les rayons externe et distal. La meilleure combinaison de température et de durée pour effectuer une lésion avec l'électrode Tew est de $80^{\circ} \mathrm{C}$ pendant $60 \mathrm{~s}$ à $90 \mathrm{~s}$.

$\mathrm{R}$ adiofrequency (RF) thermocoagulation has been used clinically as a modality to treat chronic pain since the 1950s (1); presently, it is one of the most frequently used neurolytic techniques for the relief of pain.

High-frequency electrical current is applied adjacent to the structure of the nerve that is to be ablated, leading to ionic oscillation and frictional dissipation of the ions and electrolytes, which produces heat. Thus, the main advantage of RF is more reliable and reproducible lesion production at a desired specific neurological location compared with electrocautery (2). The lesion size and shape produced by RF thermocoagulation is determined by various parameters, such as temperature, electrode configuration and the characteristics of the tissue (3). Information regarding the lesion size generated using different parameters would increase the efficacy of the technique and reduce the incidence of side effects.
Many studies involving RF lesions have been reported, including those regarding lesion shapes generated using various electrodes (4-7). Egg whites have been used in many studies to determine the size and shape of RF lesions. Because egg whites do not precisely model neural tissue, their use in in vitro studies is limited. However, egg whites are composed primarily of pure protein, a composition similar to that of human nerve tissue, and its transparency facilitates observation of changes in the lesions (8).

Since 1974, when Sweet and Wepsic (9) first described a technique for generating RF lesions in the Gasserian ganglion for the treatment of trigeminal neuralgia, RF thermocoagulation of the Gasserian ganglion has been used for treatment of idiopathic trigeminal neuralgia, atypical trigeminal neuralgia, atypical facial pain, intractable ocular pain, cluster headache and cancer pain (10). Due to the unique anatomical position of the Gasserian ganglion, the Tew electrode was developed as a new

${ }^{1}$ Department of Anesthesiology and Pain Medicine; ${ }^{2}$ Department of Neurology, College of Medicine, Hallym University, Chuncheon; ${ }^{3}$ Department of Dentistry, Gangneung-Wonju National University, Gangneung; ${ }^{4}$ Department of Anesthesiology and Pain Medicine, Sanggye Paik Hospital,

College of Medicine, Inje University, Seoul, Korea

Correspondence: Dr So Young Lim, Department of Anesthesiology, Hallym University, College of Medicine, 153 Kyo-Dong, Chuncheon, Kangwon Province, 200-704, Republic of Korea. Telephone 82-33-240-5154, fax 82-33-251-0941, e-mail inooim@hallym.or.kr 


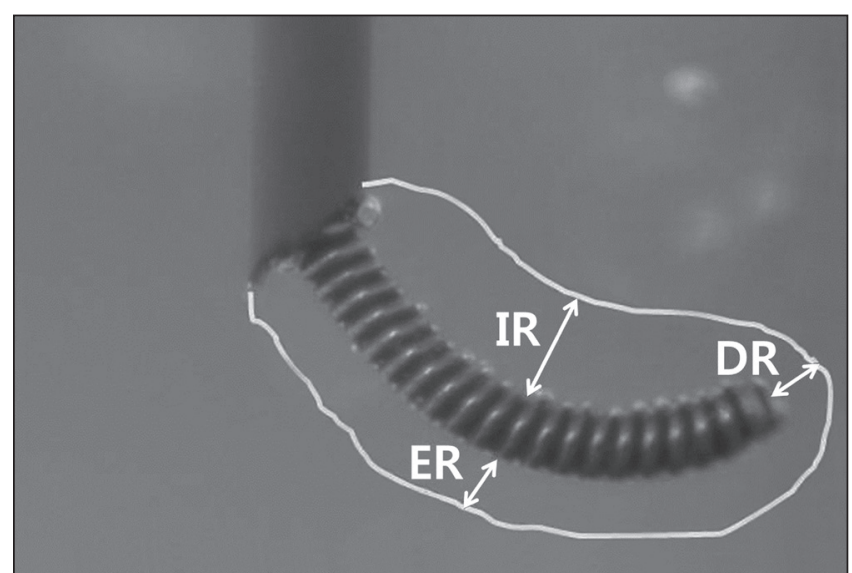

Figure 1) Determination of the radius of a lesion generated using the Tew electrode (Tew-CTC, Radionics, USA) in egg white. DR Distal radius; ER External radius; IR Internal radius

flexible curved electrode, virtually eliminating complication (11). The flexible curved electrode permits more precise positioning of the electrode tip than a straight electrode, resulting in generation of discrete lesions and decreasing the incidence of sensory and motor side effects (12). Despite the above-mentioned advantage of the Tew electrode, its lesion size and shape have not been investigated extensively.

Therefore, using egg whites, we measured and analyzed the size and shape of lesions produced by the application of the Tew electrode for different temperatures and times. The resulting data will facilitate the use of RF in chronic pain management.

\section{METHODS}

The white from a fresh hen's egg was placed in a rectangular glass container and warmed in a water bath to $37^{\circ} \mathrm{C}$. The Tew electrode set was fixed to a sponge on the upper surface of the container, and a thin metal plate, the ground electrode, was inserted into the egg white and suspended in a distant corner of the container. The Tew cannula and electrode (Tew-CTC; Radionics, USA) were inserted into the egg white. The Tew electrode is a flexible curved electrode $0.5 \mathrm{~mm}$ in diameter with an active tip $5 \mathrm{~mm}$ in length. RF was applied through the electrode using an RF lesion generator system (RFG-3C; Radionics, USA). RF lesions were produced by the Tew electrode at $65^{\circ} \mathrm{C}, 70^{\circ} \mathrm{C}, 75^{\circ} \mathrm{C}, 80^{\circ} \mathrm{C}$, $85^{\circ} \mathrm{C}$ and $90^{\circ} \mathrm{C}$. For each temperature, photographs were taken at $10 \mathrm{~s}$, 20 s, 30 s, 40 s, 50 s, 60 s, 70 s, 80 s, 90 s, 100 s, 110 s and 120 s. Lesion production was repeated five times for a total of 360 lesions $(12 \times 6 \times 5=360)$. The target temperature was reached by elevating the temperature at a rate of $6^{\circ} \mathrm{C} / \mathrm{s}$ to $9^{\circ} \mathrm{C} / \mathrm{s}$. Measuring the lesion size began when the target temperature was reached. Coagulation was defined when the transparent egg white became hazy and whitish. The transparency of the egg white and glass container enabled the changes in size of the RF lesions over time to be photographed. The magnification ratio was calculated by comparing the diameter of the real electrode with the diameter of the electrode measured on the photograph. The internal radius (IR) and external radius (ER) of the lesions were then measured, and the distal radius (DR) from the tip of the lesion from the active tip of the electrode was determined. The IR of the lesion was the perpendicular distance from the internal side of the midpoint of the electrode to the furthest point on the perimeter of the lesion. The ER of the lesion was the perpendicular distance from the external side of the lesion. The DR was the distance from the tip of the electrode to the furthest point on the lesion in line with the long axis of the electrode (Figure 1). A mixed model in SPSS version 21.0 (IBM Corporation, USA) was used to compare lesion size according to temperature and time of application. $\mathrm{P}<0.05$ was deemed to indicate statistical significance.

\section{RESULTS}

The Tew electrode produced lesions following the contour of the tip (Figure 2). The size of the lesions increased with increasing

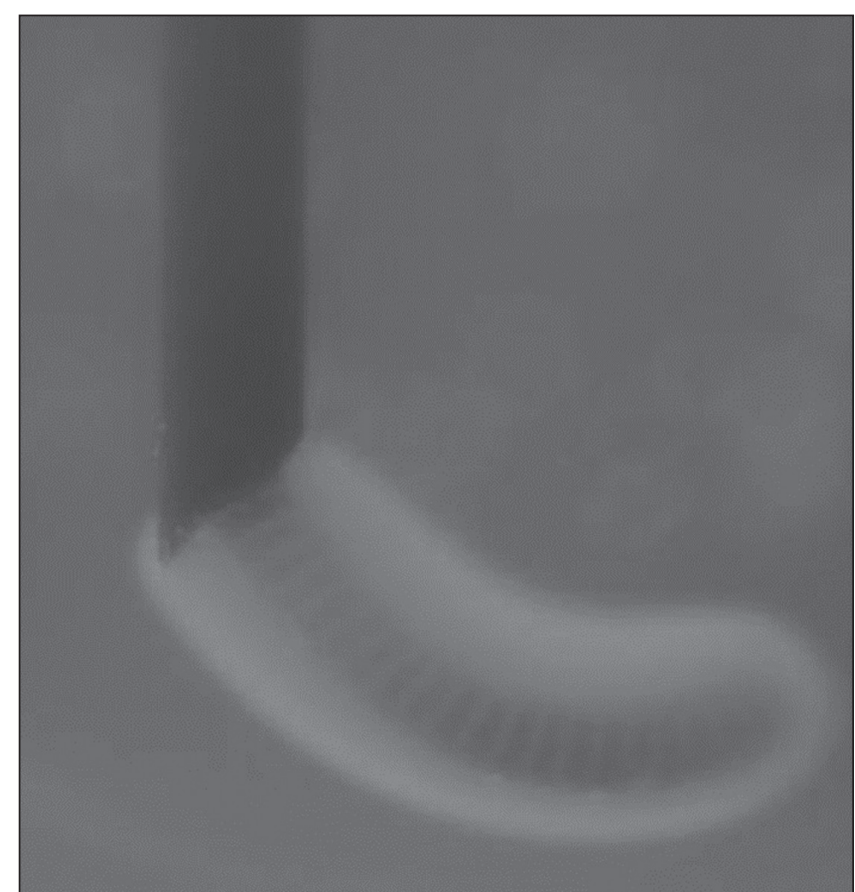

Figure 2) Photograph of a lesion generated in egg white using the Tew electrode (Tew-CTC, Radionics, USA) at $75^{\circ} \mathrm{C}$ for $30 \mathrm{~s}$

temperature and time, and the IR was larger than the ER and DR in egg white (Figure 3). The maximum lesion size was generated at $90^{\circ} \mathrm{C}$ and $120 \mathrm{~s}$, and was $1.06 \pm 0.16 \mathrm{~mm}$ in $\mathrm{IR}, 0.37 \pm 0.15 \mathrm{~mm}$ in ER and $0.39 \pm 0.04 \mathrm{~mm}$ in DR from the tip. The IR of the lesion increased with temperature, and there were statistically significant differences between the $65^{\circ} \mathrm{C}$ and $70^{\circ} \mathrm{C}$ groups and the $70^{\circ} \mathrm{C}$ and $75^{\circ} \mathrm{C}$ groups (Figure 4A). A similar pattern was observed for the ER, and there was a statistically significant difference between the $70^{\circ} \mathrm{C}$ and $75^{\circ} \mathrm{C}$ groups (Figure 4B). As the temperature of electrodes were increased, $\mathrm{DR}$ of the tip gradually increased from $60^{\circ} \mathrm{C}$ to $80^{\circ} \mathrm{C}$. However, there were no significant differences of DR above $80^{\circ} \mathrm{C}$ (Figure $4 \mathrm{C}$ ). The IR, ER and DR of lesions increased significantly with application time, from $10 \mathrm{~s}$ to $120 \mathrm{~s}$, at the same temperature. However, the lesion sizes increased with application time at the same temperature without statistical significance among the time groups.

\section{DISCUSSION}

$\mathrm{RF}$ thermocoagulation has been used for the treatment of conditions including chronic pain, malignant tumour and cardiac arrhythmia. RF thermocoagulation enables reliable formation of discrete thermal lesions in a desired specific neurological location (10). As a mechanism of RF, some authors have demonstrated that the compound action potentials of A-delta and $\mathrm{C}$ fibres in nerves are blocked at lower temperatures compared with those of the larger $\mathrm{A}$-alpha and A-beta fibres $(13-15)$. However, this concept is controversial and was contradicted by multiple histological studies $(16,17)$. The current rationale is that RF lesions lead to nonselective heat destruction of all fibres in the centre of the lesion; at the periphery of the lesion, there is selective destruction of more vulnerable, small fibres with preservation of the larger fibres $(18,19)$.

Although RF for the treatment of chronic pain has proven to be an effective, minimally invasive treatment, it has inherent risks and complications. Because the heating radius of a small needle is limited, the needle must be placed exactly on the nerve to guarantee its coagulation (8). The lesion size varies depending on the shape, thickness and length of the noninsulated electrode tip, and with the time and temperature of application (3). Therefore, information regarding the lesion size, generated using different parameters, would increase the efficacy of the technique and reduce the incidence of side effects. 


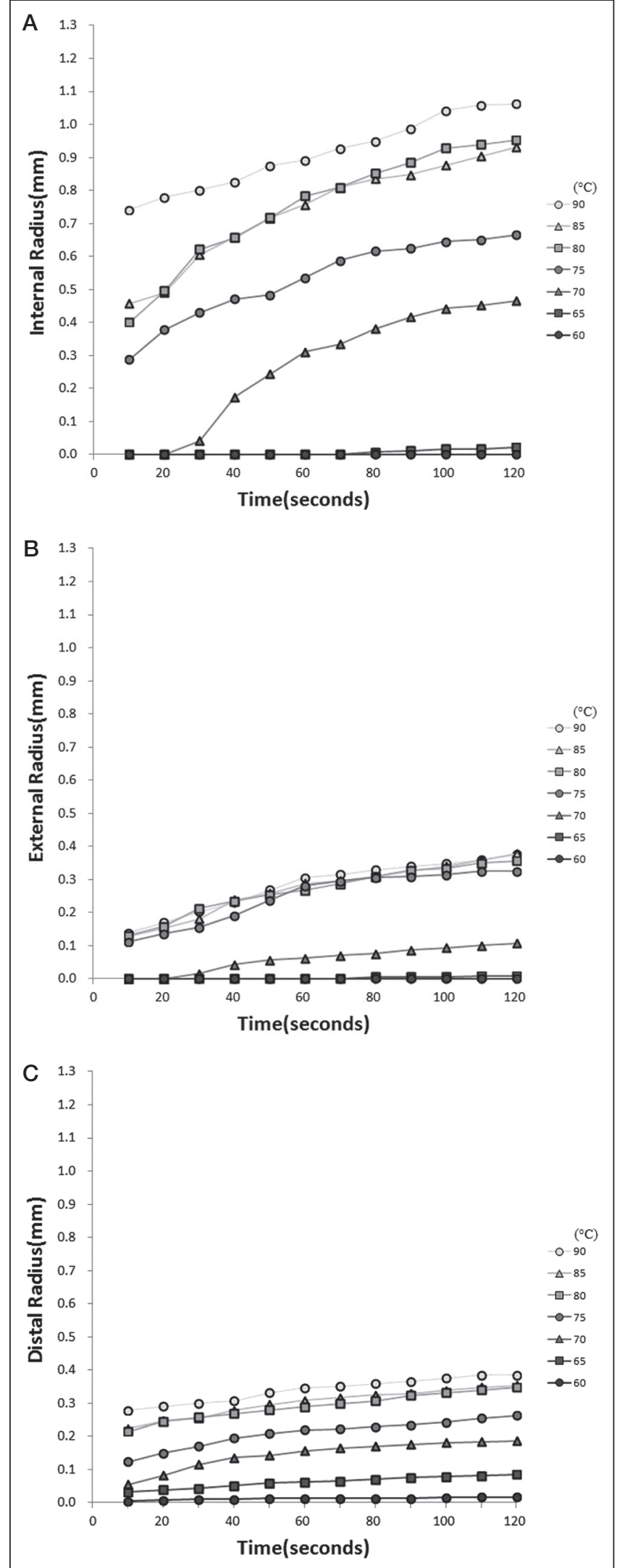

Figure 3) The size of lesions generated in egg white by radiofrequency using the Tew electrode (Tew-CTC, Radionics, USA) at different temperatures and times. Changes in size (mean) of the (A) internal radius, (B) external radius and $(\mathrm{C})$ distal radius. Figures were created using Microsoft Excel 2007 (Mircosoft Corporation, USA)

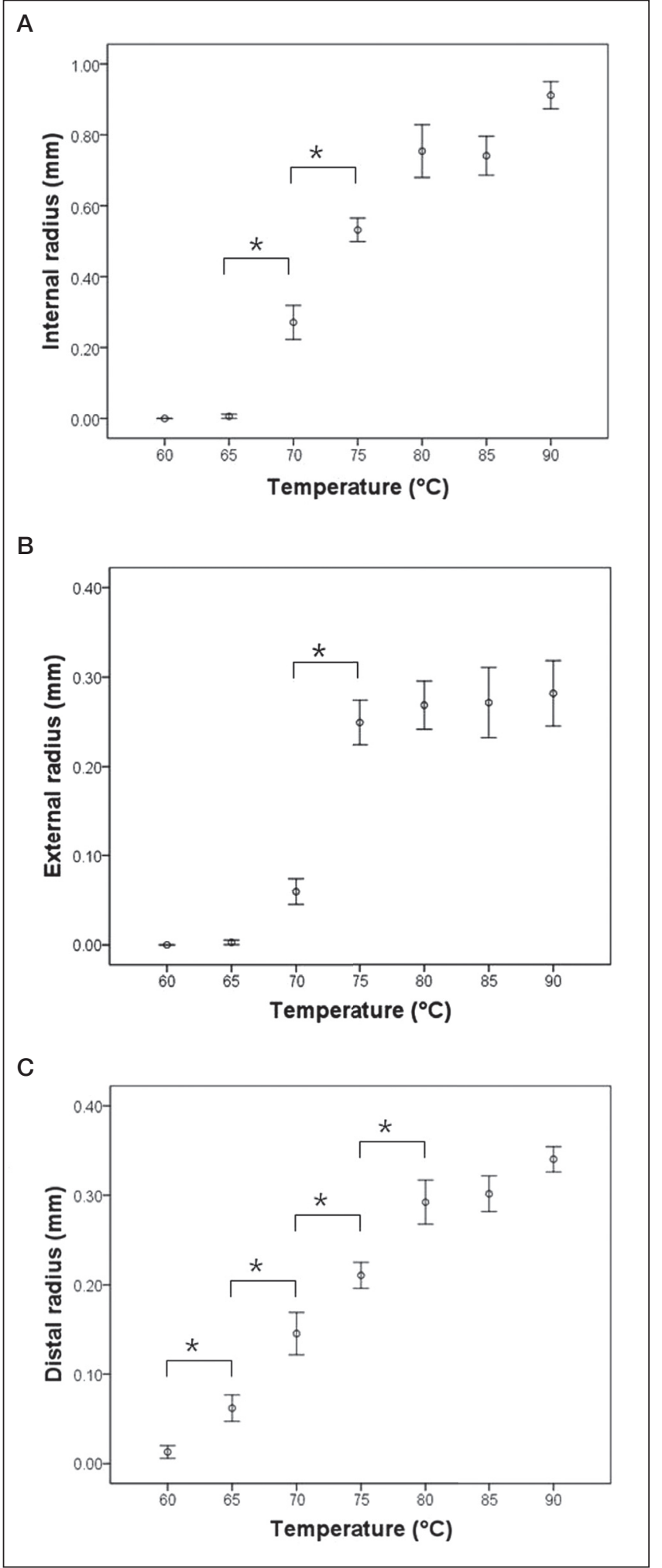

Figure 4) Analysis of the size of lesions generated in egg white using the Tew electrode (Tew-CTC, Radionics, USA) at different temperatures. A The internal radius increased with temperature and statistically significant differences were noted between the $65^{\circ} \mathrm{C}$ and $70^{\circ} \mathrm{C}$ groups and between the $70^{\circ} \mathrm{C}$ and $75^{\circ} \mathrm{C}$ groups. B The external radius increased with temperature and there was a statistically significant difference between the $70^{\circ} \mathrm{C}$ and $75^{\circ} \mathrm{C}$ groups. $\mathrm{C}$ As the tempeaure of electrodes were increased, distal radius of the tip gradually increased from $60^{\circ} \mathrm{C}$ to $80^{\circ} \mathrm{C}$. However, there were no significant differences of distal radius above $80^{\circ} \mathrm{C}$. $* P<0.05$ 
The goal of RF treatment of trigeminal neuralgia is to achieve total pain relief while preserving trigeminal sensation (20). The most prevalent complications of RF treatment are sensory loss in the treated branch or paralysis of the masseter muscle. In the long term, anesthesia dolorosa, corneal hypoesthesia and keratitis, and temporary paralysis of the third and fourth cranial nerve can occur (21). Several improvements have been developed to minimize unwanted side effects. The innovation of RF thermocoagulation by the Tew, van Loveren, and Keller group included both the introduction of the Tew curved-tip electrode (11), and the modification of the technique for cannulation of the foramen ovale using image-guided fluoroscopy (22). The Tew electrode was developed as a new flexible curved-tip electrode that has virtually eliminated motor root dysfunction. The tip of the curved electrode extends $5 \mathrm{~mm}$ in an axial direction from the distal end of the cannula, and the electrode has a rounded distal end to avoid any cutting action and is $0.5 \mathrm{~mm}$ in diameter (9). Manipulation of the electrode about its $360^{\circ}$ axis enables an infinite variety of position adjustments of the electrode tip. The incidence of masseter weakness and paresthesia has decreased compared with that in patients treated with a straight electrode (23). However, despite the above-mentioned advantages, the size and shape of lesions generated using the Tew curved-tip electrode have not been reported. Therefore, our data may facilitate the design of clinical trials that produce an adequate lesion during RF treatment using the Tew electrode.

The size of the lesions may vary in vivo, depending on factors such as vascularity and tissue heat conductivity (24). Computed tomography and magnetic resonance imaging are the only modalities for estimating the size and shape of the lesions in the human brain. However, these techniques are not sufficient to evaluate correlations between lesion shape and electrode configuration; additionally, the results of early postoperative imaging of lesions are difficult to interpret because of tissue swelling and edema $(25,26)$. The in vitro study by Eriksson et al (27), revealed that the real lesion size in tissue may be greater than that in albumin because electrical resistance is greater in tissue than in albumin. Nevertheless, egg whites seemed a suitable medium in which to examine lesion production because RF treatment denatures proteins, of which an egg white is predominantly comprised. In a previous report (8), monopolar lesions produced in both egg whites and skeletal muscle were similar in geometry and size to those produced in brain tissue. Moreover, the translucency of the egg white allows visualization and measurement of the lesions as they are created (6). There are many combined studies involving in vitro lesioning and its clinical application $(28,29)$, and lesion size in egg whites was useful as a reference for clinical application.

Using a straight or curved electrode, the lesion extends radially around the electrode tip in the shape of an oblate spheroid (30). The lesion is an oval shape parallel to the needle that usually does not exceed the tip of the needle; thus, ideally, the needle should be parallel to the targeted nerve (31). Theoretically, the lesion size is dependent on the heat generated, the heat loss and the electrode size. The generated heat is inversely proportional to the fourth power of the distance from the electrode, proportional to the second power of the current, and linearly proportional to the duration of lesioning (32). However, in our study where a Tew electrode was used, the lesion size was not an exact function of temperature or time. Our results reveal that the Tew curved electrode produced lesions following the contour of the tip, and the lesions exceed the tip of the needle. Lesion size differed depending on the IR, ER and DR from the tip. The IR was larger than the ER and DR. The latter finding is noteworthy because of the possibility for manipulation of the Tew electrode about its $360^{\circ}$ axis (33).

Previous reports have demonstrated the importance of temperature monitoring for predicting lesion size (34). Our data also show that temperature was an important determinant of lesion size. Lesion size increased significantly with increment of temperature. Lesion IR increased significantly between the $65^{\circ} \mathrm{C}$ and $70^{\circ} \mathrm{C}$ groups and $70^{\circ} \mathrm{C}$ and $75^{\circ} \mathrm{C}$ groups, and lesion ER between the $70^{\circ} \mathrm{C}$ and $75^{\circ} \mathrm{C}$ groups. DR of the tip gradually increased from $60^{\circ} \mathrm{C}$ to $80^{\circ} \mathrm{C}$, but there were no significant differences of DR above $80^{\circ} \mathrm{C}$. These results suggest that temperatures $>80^{\circ} \mathrm{C}$ would not result in a significant change in the ER, IR and DR of the lesion. Consistency of lesion size is achieved by letting the lesion come to thermal equilibrium. The nominal radius of the lesion approaches a maximum value as equilibrium between the $\mathrm{RF}$ heat into and the heat conduction away from the tissue around the tip is established. In our experiment, the peak effect appears as a result of the thermal equilibrium process, and there was no statistical significance in changes of the lesion size above $80^{\circ} \mathrm{C}$. Higher temperatures may result in gas formation, tissue adherence to the probe, tearing and hematoma formation with changes in electrode position (35). Popped lesions may be caused by tissue boiling and gas formation (36), resulting in damage to adjacent neural structures. Popped lesions are associated with the rate of increase in tip temperature (2). When heat spreads too rapidly, scattered areas of explosive water vapourization are produced, resulting in an irregularly shaped lesion larger than the desired volume. Bogduk et al (8) increased the temperature of the tip at a rate of $1^{\circ} \mathrm{C}$ to $2^{\circ} \mathrm{C}$ per second in their study; however, Eriksson et al (27) and the present study both increased the temperature of the tip at a rate of $6^{\circ} \mathrm{C} / \mathrm{s}$ to $9^{\circ} \mathrm{C} / \mathrm{s}$. Because there were no popped lesions in the present study, the rate of increase in temperature did not lead to gas formation or tissue boiling.

Increased duration of application has a lesser effect on lesion size than increasing temperature (2). In the present study, lesion size increased significantly as application duration was raised from $10 \mathrm{~s}$ to $120 \mathrm{~s}$, but no significant differences were found among the time groups. Because the time of application at a constant temperature is less critical in determining the lesion's size, the use of longer durations is not recommended. However, a minimum time has to be exceeded before the lesion approaches its maximum possible size. As a general rule, satisfactory lesion durations are $30 \mathrm{~s}$ for small lesions (eg, percutaneous cordotomy) and $60 \mathrm{~s}$ to $90 \mathrm{~s}$ for large lesions (eg, Gasserian ganglionectomy, thalamotomy) (2).

Larger lesions can reduce the likelihood of missing a target nerve and increase the number and extent of target nerves captured by each lesion (37). This may help to avoid incomplete neurolysis, to improve the degree and duration of pain relief, and to reduce procedure time and $\mathrm{x}$-ray exposure. However, larger lesions may also increase the likelihood and severity of damage to nontarget nerves, skin burns in thin patients and postprocedural paresthesia (38). The ideal technique places the smallest lesion possible in the nervous system, exactly at the target structure, with full lesion controllability and without causing complications and discomfort to the patient (10). Therefore, in our experiment, the best combination of temperature and time was $80^{\circ} \mathrm{C}$ for $60 \mathrm{~s}$ to $90 \mathrm{~s}$.

In our study, the lesion size attained using the Tew electrode in an egg white increased with increasing temperature and time, but time had a lesser effect on lesion size than temperature. The Tew electrode produced lesions following the contour of the tip, and the IR was larger than the ER and DR. The best combination of temperature and time for lesioning was $80^{\circ} \mathrm{C}$ for $60 \mathrm{~s}$ to $90 \mathrm{~s}$. Although our study was an in vitro experiment using egg whites, we believe that our results will be valuable data for RF treatment in a clinical setting.

\section{CONCLUSION}

The Tew electrode produces lesions following the contour of the tip, and the IR is larger than the ER and DR in egg whites. The lesion size increases with increasing temperature and time. The best combination of temperature and time for lesioning using a Tew electrode is $80^{\circ} \mathrm{C}$ for $60 \mathrm{~s}$ to $90 \mathrm{~s}$. We believe that our data will facilitate expansion of the applications of Tew curved electrodes and provide information useful for clinical trials.

DISCLOSURES: The authors have no financial relationships or conflicts of interest to declare. 


\section{REFERENCES}

1. Mullan S, Harper PV, Hekmatpanah J, Torres H, Dobbin G. Percutaneous intrerruption of spinal-pain tracts by means of a strontium90 needle. J Neurosurg 1963;20:931-9.

2. Organ LW. Electrophysiologic principles of radiofrequency lesion making. Appl Neurophysiol 1976-1977;39:69-76.

3. Alberts WW, Wright EW Jr, Feinstein B, Von Bonin G. Experimental radiofrequency brain lesion size as a function of physical parameters. J Neurosurg 1996;25:421-3.

4. Cohen SP, Hurley RW, Buckrnmaier CC III, Kurihara C, Morlando B, Dragovich A. Randomized placebo-controlled study evaluating lateral branch radiofrequency denervation for sacroiliac joint pain. Anesthesiology 2008;109:279-88.

5. Heavner JE, Boswell MV, Racz GB. A comparison of pulsed radiofrequency and continuous radiofrequency on thermocoagulation of egg white in vitro. Pain Physician 2006;9:135-7.

6. Pino CA, Hoeft MA, Hofsess C, Rathmell JP. Morphologic analysis of bipolar radiofrequency lesions: Implications for treatment of the sacroiliac joint. Reg Anesth Pain Med 2005;30:335-8.

7. Vinas FC, Zamorano L, Dujovny M, et al. In vivo and in vitro study of the lesions produced with a computerized radiofrequency system. Stereotact Funct Neurosurg 1992;58:121-33.

8. Bogduk N, Macintosh J, Marsland A. Technical limitations to the efficacy of radiofrequency neurotomy for spinal pain. Neurosurgery 1987;20:529-35.

9. Sweet WH, Wepsic JG. Controlled thermocoagulation of trigeminal ganglion and rootlets for differential destruction of pain fibers. 1. Trigeminal neuralgia. J Neurosurg 1974; 40:143-56.

10. Kline MT, Yin W. Radiofrequency techniques in clinical practice. In: Waldman SD, eds. Interventional Pain Management, 2 nd edn. Philadelphia: WB Saunders, 2001:243-93.

11. van Loveren H, Tew JM Jr, Keller JT, Nurre MA. A 10-year experience in the treatment of trigeminal neuralgia. Comparison of percutaneous stereotaxic rhizotomy and posterior fossa exploration. J Neurosurg 1982;57:757-64.

12. Tobler WD, Tew JM Jr, Cosman E, Keller JT, Quallen B. Improved outcome in the treatment of trigeminal neuralgia by percutaneous stereotactic rhizotomy with a new, curved tip electrode. Neurosurgery 1983;12:313-7.

13. Cobb CA III, Fung D. Quantitative analysis of lesion parameters in radiofrequency trigeminal rhizotomy. J Neurosurg 1983;58:388-91.

14. Frigyesi TL, Siegfried J, Broggi G. The selective vulnerability of evoked potentials in the trigeminal sensory root of graded thermocoagulation. Exp Neurol 1975;49:11-21.

15. Sluijter ME, Koetsveld-Baart CC. Interruption of pain pathways in the treatment of the cervical syndrome. Anaesthesia 1980;35:302-7.

16. Slappendel R, Crul BJ, Braak GJ, et al. The efficacy of radiofrequency lesioning of the cervical spinal dorsal root ganglion in a double blinded randomized study: No difference between 40 degrees $C$ and 67 degrees $C$ treatments. Pain 1997;73:159-63.

17. Smith HP, McWhorter JM, Challa VR. Radiofrequency neurolysis in a clinical model. Neuropathological correlation. J Neurosurg 1981;55:246-53.

18. Koning MV, Koning NJ, Koning HM, van Kleef M. Relationship between sensory stimulation and side effects in percutaneous radiofrequency treatment of the trigeminal ganglion. Pain Pract 2013;24:1-7.

19. van Kleef M, Barendse GA, Dingemans WA, et al. Effects of producing a radiofrequency lesion adjacent to the dorsal root ganglion in patients with thoracic segmental pain. Clin J Pain 1995;11:325-32.
20. Taha JM, Tew JM Jr, Buncher CR. A prospective 15-year follow up of 154 consecutive patients with trigeminal neuralgia treated by percutaneous stereotactic radiofrequency thermal rhizotomy. J Neurosurg 1995;83:989-93.

21. Kanpolat Y, Savas A, Bekar A, Berk C. Percutaneous controlled radiofrequency trigeminal rhizotomy for the treatment of idiopathic trigeminal neuralgia: 25-year experience with 1,600 patients. Neurosurgery 2001;48:524-32.

22. Tew JM Jr, Keller JT, Williams DS. Application of stereotactic principles to the treatment of trigeminal neuralgia. Appl Neurophysiol 1978;41:146-56.

23. Baggenstos M, Chew E, Butman JA, Oldfield EH, Lonser RR. Progressive peritumoral edema defining the optic fibers and resulting in reversible visual loss. J Neurosurg 2008;12:313-7.

24. Derby R, Lee CH. The efficacy of a two needle electrode technique in percutaneous radiofrequency rhizotomy: An investigational laboratory study in an animal model. Pain Physician 2006;9:207-13.

25. Hariz MI. Correlation between clinical outcome and size and site of the lesion in computed tomography guided thalamotomy and pallidotomy. Stereotact Funct Neurosurg 1990;54-55:172-85.

26. Tomlinson FH, Jack CR Jr, Kelly PJ. Sequential magnetic resonance imaging following stereotactic radiofrequency ventralis lateralis thalamotomy. J Neurosurg 1991;74:579-84.

27. Eriksson O, Wådell K, Bylund NE, Kullberg G, Rehncrona S. In vitro evaluation of brain lesioning electrode (Leksell) using a computer-assisted video system. Neurol Res 1999;21:89-95.

28. Oh MY, Hodaie M, Kim SH, Alkhani A, Lang AE, Lozano AM. Deep brain stimulator electrodes used for lesioning: Proof of principle. Neurosurgery 2001;49:363-7.

29. Buijs EJ, van Wijk RM, Geurts JW, Weeseman RR, Stolker RJ, Groen GG. Radiofrequency lumbar facet denervation: A comparative study of the reproducibility of lesion size after 2 current radiofrequency techniques. Reg Anesth Pain Med 2004;29:400-7.

30. Moringlane JR, Koch R, Schäfer H, Ostertag CB. Experimental radiofrequency (RF) coagulation with computer-based on line monitoring of temperature and power. Acta Neurochir (Wien) 1989;96:126-31.

31. Soloman M, Mekhail MN, Mekhail N. Radiofrequency treatment in chronic pain. Expert Rev Neurother 2010;10:469-74.

32. Vervest ACM, Stolker RJ, Groen GJ. Radiofrequency lesioning for pain treatment: A review. The Pain Clinic 1995;8:175-189.

33. Kim KS, Ko HH, Hwang SM, Lim SY, Hong SY, Shin KM. Stereotactic neurotomy of the ganglion impar through the sacrococcygeal junction in cancer-related perineal pain. Korean J Pain 2005;18:263-6.

34. Cosman ER, Nashold BS, Bedenbaugh P. Stereotactic radiofrequency lesion making. Appl Neurophysiol 1983;46:160-6.

35. Cosman ER, Cosman BJ. Methods of making nervous system lesions. In: Wilkins RH, Rengachary SS, eds. Neurosurgery. New York: Mcgraw-Hill, 1984:2490-9.

36. White JC, Sweet WH. Pain and the Neurosurgeon. Springfield: Charles C Thomas, 1969:594-621.

37. Cosman ER Jr, Gonzalez CD. Bipolar radiofrequency lesion geometry: Implications for palisade treatment of sacroiliac joint pain. Pain Pract 2011;11:3-22.

38. Govind J, King W, Bailey B, Bogduk N. Radiofrequency neurotomy for the treatment of third occipital headache. J Neurol Neurosurg Psychiatry 2003;74:88-93. 


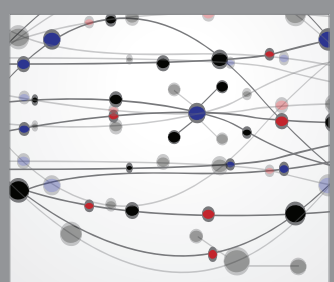

The Scientific World Journal
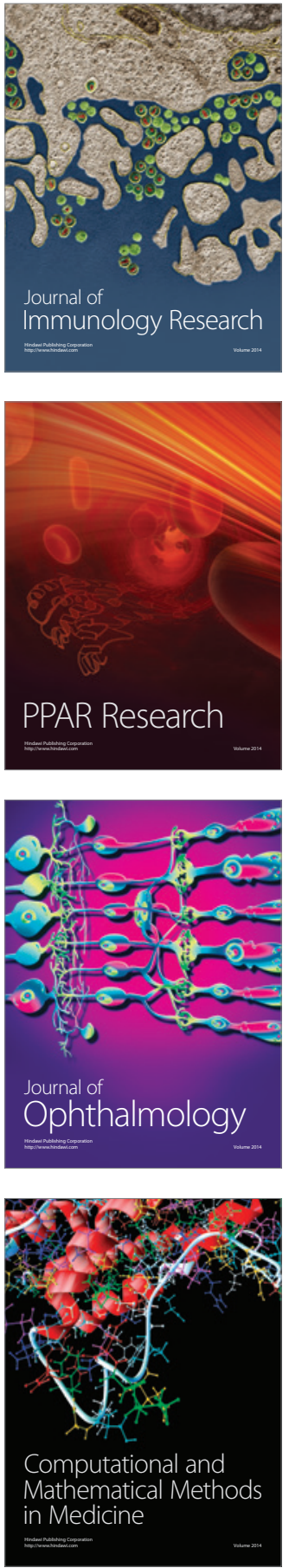

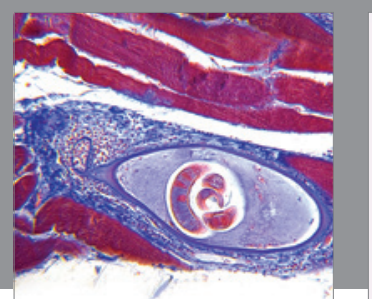

Gastroenterology Research and Practice

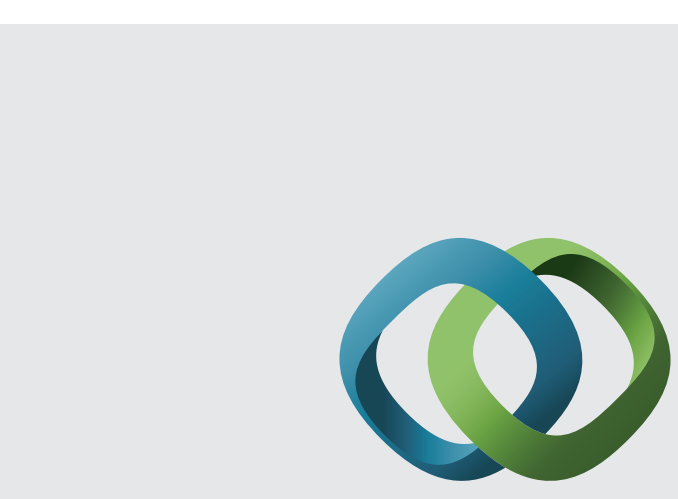

\section{Hindawi}

Submit your manuscripts at

http://www.hindawi.com
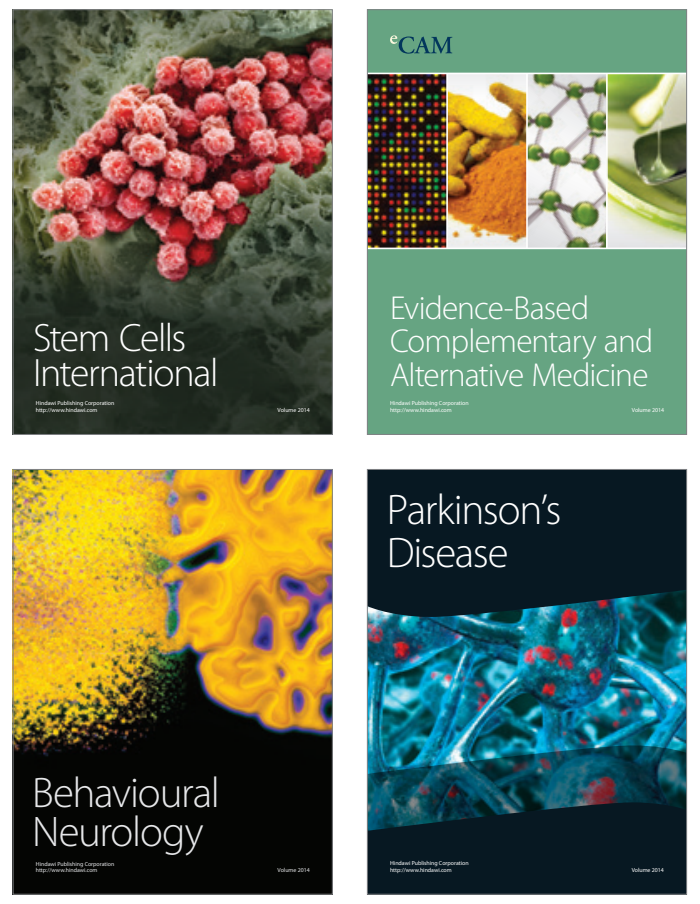
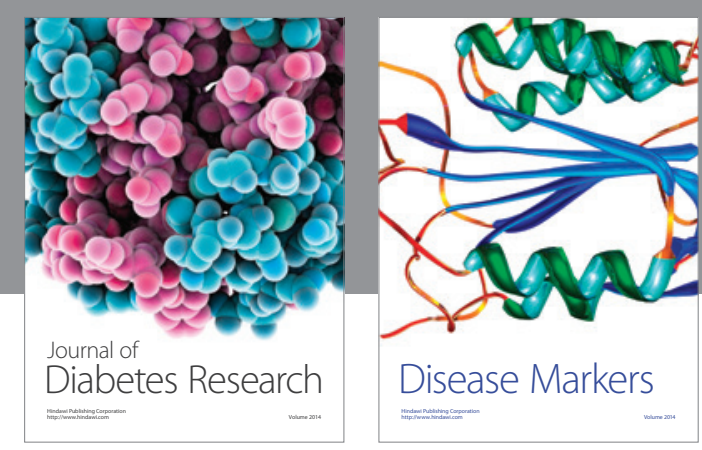

Disease Markers
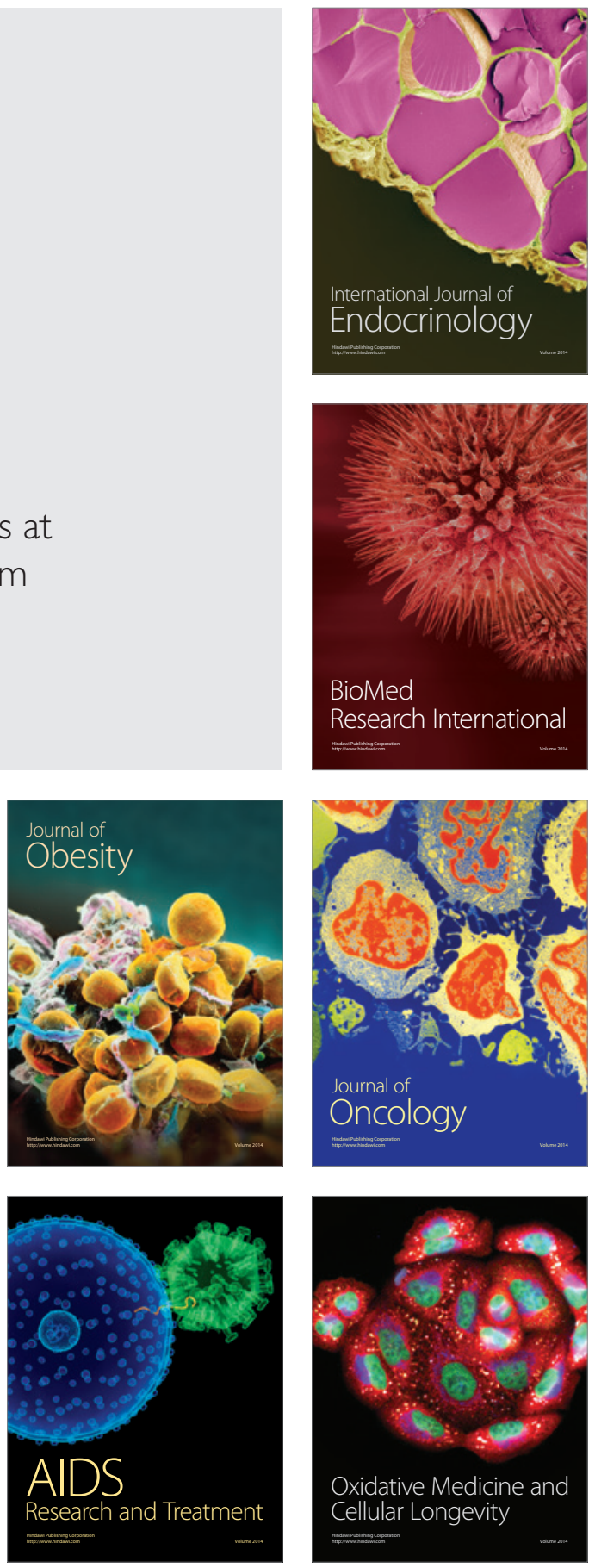